Bull. Mater. Sci., Vol. 36, No. 1, February 2013, pp. 149-152. (C) Indian Academy of Sciences.

\title{
Crystal structure studies on plate/shelf like disodium ditungstate
}

\author{
DRAGANA J JOVANOVIĆ, IVANA LJ VALIDŽIĆ**, MIODRAG MITRIĆ and \\ JOVAN M NEDELJKOVIĆ \\ Vinča Institute of Nuclear Sciences, University of Belgrade, P.O. Box 522, 11001 Belgrade, Serbia
}

MS received 17 March 2011; revised 14 December 2011

\begin{abstract}
The structure of plate/shelf like disodium ditungstate $\left(\mathrm{Na}_{2} \mathrm{~W}_{2} \mathrm{O}_{7}\right)$ synthesized by new method in the process of ultrasonic spray pyrolysis using acidified aqueous solutions of tungsten (VI) oxide clusters as a precursor was refined down to the $\boldsymbol{R}$-factor of $\mathbf{8 . 9 \%}$. X-ray diffraction analysis undoubtedly confirmed formation of orthorhombic $\mathrm{Na}_{2} \mathrm{~W}_{2} \mathrm{O}_{7}$ and refinement of the diffraction data showed that $\mathrm{Na}_{2} \mathrm{~W}_{2} \mathrm{O}_{7}$ powder belongs to the base-centred orthorhombic type of structure with 64 space group, Cmca. The structure of $\mathrm{Na}_{2} \mathrm{~W}_{2} \mathrm{O}_{7}$ can be described as infinite chains formed from tetrahedral $\left(\mathrm{WO}_{4}\right)$ and octahedral $\left(\mathrm{WO}_{6}\right)$ building units joined together. It was found that the basic units of the precursor complexes exist in the structure of $\mathrm{Na}_{2} \mathrm{~W}_{2} \mathrm{O}_{7}$. Scanning electron microscopy confirmed formation of plate/shelf like $\mathrm{Na}_{2} \mathrm{~W}_{2} \mathrm{O}_{7}$ particles with an average thickness of about $1.2 \mu \mathrm{m}$.
\end{abstract}

Keywords. Inorganic materials; disodium ditungstate; crystal structure; scanning electron microscopy; X-ray diffraction.

\section{Introduction}

Alkaline tungstate materials possess interesting electronic and optical applications and have drawn considerable attention due to their unique properties such as successive phase transitions over a range of temperatures, low dielectric constant, high dielectric loss and high electrical conductivity (Dickens and Whittingham 1968; Choudhary and Choudhary 1998; Sharma and Choudhary 1999). Disodium ditungstate $\mathrm{Na}_{2} \mathrm{~W}_{2} \mathrm{O}_{7}$ as a stable compound has been used to reduce the sintering temperature of dielectric ceramics (Wang and Bian 2011). The luminescent properties combined with high density and strong absorption makes many tungstate compounds candidates for use in high-energy electromagnetic calorimetry (Dahlborg et al 2002; Hong et al 2006). Recently reported articles (Wei 2010; Wei et al 2011) show that the $\mathrm{Na}_{2} \mathrm{~W}_{2} \mathrm{O}_{7}$ crystal is a promising intrinsic scintillator.

In this paper, we applied ultrasonic spray pyrolysis (USP) and acidified aqueous solutions of tungsten (VI) oxide clusters (Pope 1983) as a precursor, to synthesize plate/shelf like $\mathrm{Na}_{2} \mathrm{~W}_{2} \mathrm{O}_{7}$ particles under mild experimental conditions. Metal oxides, in particular, molybdenum, tungsten, vanadium and aluminum oxide spontaneously and reversibly form clusters consisting of up to 36 monomers in acidified aqueous solutions (Baes and Mesmer 1976; Tytko and Glemser 1976). Knowing that the crystal structure of $\mathrm{Na}_{2} \mathrm{~W}_{2} \mathrm{O}_{7}$ consists of a continuous network of tungstenoxide octahedrons $\left(\mathrm{WO}_{6}\right)$ which share corner oxygen atoms, and are also attached to tungsten-oxide tetrahedrons $\left(\mathrm{WO}_{4}\right)$

\footnotetext{
*Author for correspondence (validzic@ vinca.rs)
}

(Lindqvist 1950), the precursor solution was adjusted to mainly contain polymeric complexes with 6,7 or 12 ions of W (VI) (Baes and Mesmer 1976; Tytko and Glemser 1976). In principle, polymeric complexes with 6,7 or 12 ions of $\mathrm{W}(\mathrm{VI})\left(\right.$ such as $\left[\mathrm{W}_{6} \mathrm{O}_{21}\right]^{6-},\left[\mathrm{W}_{7} \mathrm{O}_{24}\right]^{6-},\left[\mathrm{W}_{10} \mathrm{O}_{32}\right]^{4-}$, $\left[\mathrm{W}_{12} \mathrm{O}_{41}\right]^{10-},\left[\mathrm{W}_{12} \mathrm{O}_{42}\right]^{12-}$, and other isopolytungstates including those with Keggin structure) predominate at room temperature in acidic solutions, when tungsten concentration is higher than $10^{-4} \mathrm{M}$ (Baes and Mesmer 1976; Redkin and Bondarenko 2010). It is important to point out that these precursor species also have octahedral $\mathrm{WO}_{6}$ monomers (showing meshing and extension of the $\mathrm{WO}_{4}$ tetrahedral building units) linked at their vertexes.

So far, the crystal structure of the normal-pressure phase, $\mathrm{Na}_{2} \mathrm{~W}_{2} \mathrm{O}_{7}$, has been determined by Okada et al (1975). As far as we are aware no other crystallographic data have been reported to date. On the other side, due to the fact that so far, nobody presented TEM or SEM images of plate/shelf like $\mathrm{Na}_{2} \mathrm{~W}_{2} \mathrm{O}_{7}$ particles, refinement of the crystal structure of this powder compound has been determined.

\section{Experimental}

All chemicals (tungsten (VI) oxide, perchloric acid, isobutyl alcohol and sodium perchlorate) purchased from Merck (Darmstadt, Germany) were of highest purity available and they were used without further purification. Aqueous solutions of tungsten (VI) oxide clusters were prepared as described in literature (Sasaki 1961; Pope 1983). Briefly, tungsten (VI) oxide solutions were prepared at $\mathrm{pH}=4.0$ (adjusted by $\mathrm{HClO}_{4}$ ) and at constant ionic strength of $3 \mathrm{M}$ 
(adjusted by $\mathrm{NaClO}_{4}$ ). Typical total tungstate concentration in solution was $0 \cdot 1 \mathrm{M}$.

The $\mathrm{Na}_{2} \mathrm{~W}_{2} \mathrm{O}_{7}$ powders were obtained in the process of USP using solutions consisting of tungsten (VI) oxide clusters as a starting material. Laboratory set up for USP consists of ultrasonic atomizer (GAPUSOL-RBI-91-012, Sarl, France) operating at a frequency of $1.7 \mathrm{MHz}$ for aerosol generation, and horizontal electric furnace with quartz tube and a vessel for particle collection. The effective heating length of reactor tube was $1 \mathrm{~m}$ with a maximum temperature of $300{ }^{\circ} \mathrm{C}$ in middle of the furnace. The flow rate of air was $30 \mathrm{dm}^{3}$ per $\mathrm{h}$. The flow rate of aerosol droplets was assumed to be equal to the flow rate of gas carrier and residence time of aerosol droplets in the furnace was found to be $1 \mathrm{~min}$.

The obtained $\mathrm{Na}_{2} \mathrm{~W}_{2} \mathrm{O}_{7}$ powders were collected in isobutyl alcohol and particles were separated from solvent containing excess of electrolytes immediately after synthesis by using ultra-centrifugation. Synthesized $\mathrm{Na}_{2} \mathrm{~W}_{2} \mathrm{O}_{7}$ particles were washed several times with isobutyl alcohol and annealed at $500{ }^{\circ} \mathrm{C}$ for 4 days.

Scanning electron microscopy (SEM) was performed using JEOL JSM-6460LV instrument (Tokyo, Japan). The $\mathrm{Na}_{2} \mathrm{~W}_{2} \mathrm{O}_{7}$ samples were coated with thin layer of gold deposited by sputtering process. The thickness of the gold film was up to $40-50 \mathrm{~nm}$.

The X-ray powder diffraction (XRPD) patterns of investigated samples were obtained on a Philips PW-1050 automated diffractometer using Ni-filtered $\mathrm{CuK}_{\alpha}$ radiation (operated at $40 \mathrm{kV}$ and $30 \mathrm{~mA}$ ). A fixed $1^{\circ}$ divergence and $0 \cdot 1^{\circ}$ receiving slits were used. Diffraction data for structural analysis were collected in the $2 \theta$ range from 10 to $120^{\circ}$, with $0.02^{\circ}$ steps and $12 \mathrm{~s}$ exposition per step. Structural analysis was performed by using the KOALARIE computing program (Cheary and Coelho 1992) based on the Rietveld full profile refinement method (Rietveld 1969). This program is suitable to obtain microstructural parameters such as crystallite size, microstrain, and the $R$ factor (Cheary and Coelho 1992). Samples for XRPD measurements were prepared using the standard protocol (Pecharsky and Zavalij 2005).

\section{Results and discussion}

Typical SEM image of the $\mathrm{Na}_{2} \mathrm{~W}_{2} \mathrm{O}_{7}$ particles collected after USP in isobutyl alcohol and separated from the solvent by ultra-centrifugation is shown in figure 1. Most of the particles are plate/shelf like with an average thickness of about $1.20 \mu \mathrm{m}$. As far as we are aware only Chatterjee (2004) presented SEM image of the agglomerated disodium ditungstate particles. Chai et al (2007) synthesized $\mathrm{Na}_{2} \mathrm{~W}_{2} \mathrm{O}_{7}$ nanotube and dendrimer, through the surface sol-gel process and Kim et al (2009) reported bundles or rod-shaped $\mathrm{Na}_{2} \mathrm{~W}_{2} \mathrm{O}_{7}$ film.

Solid materials obtained in the process of USP collected in isobutyl alcohol, thoroughly washed and annealed at $500{ }^{\circ} \mathrm{C}$ were analysed using XRD measurements. The refinement of the diffraction data showed that $\mathrm{Na}_{2} \mathrm{~W}_{2} \mathrm{O}_{7}$ powder belongs to the base-centred orthorhombic type of structure. The structure refinements were done in the 64 space group, Cmca. The obtained values are in reasonable agreement with data reported by Okada et al (1975), although slight differences in interatomic distances and bond angles exist. No traces of any other crystalline phase were noticed in the samples collected in isobutyl alcohol.

Results of the final Rietveld refinements (the unit cell dimensions) are presented in table 1 and the final Rietveld plot is depicted in figure 2. The crystallite size and micro strain of the whole pattern are $1511.11 \mathrm{~nm}$ and $0.006 \%$, respectively. The structure of disodium ditungstate was refined down to the $R_{\mathrm{p}}$-factor of $8.9 \%\left(R_{\mathrm{wp}}=8.4 \% ; R_{\exp }=\right.$ $\left.8.6 \% ; R_{\mathrm{B}}=6.2 \%\right)$. Values of estimated standard deviations as well as reliability factors confirmed that these data are reliable and that structure was well refined. Based on the fixed and refined fraction coordinates of the ions, interatomic distances and bond angles in $\mathrm{Na}_{2} \mathrm{~W}_{2} \mathrm{O}_{7}$ (octahedron and tetrahedron) were determined and presented in table 2 with their estimated standard deviations. Distortion of the tetrahedron (W (2) atom is tetrahedrally surrounded by four oxygen atoms) is rather small, while distortion of the octahedron (W (1) atom is octahedrally surrounded by six oxygen atoms) is quite large.

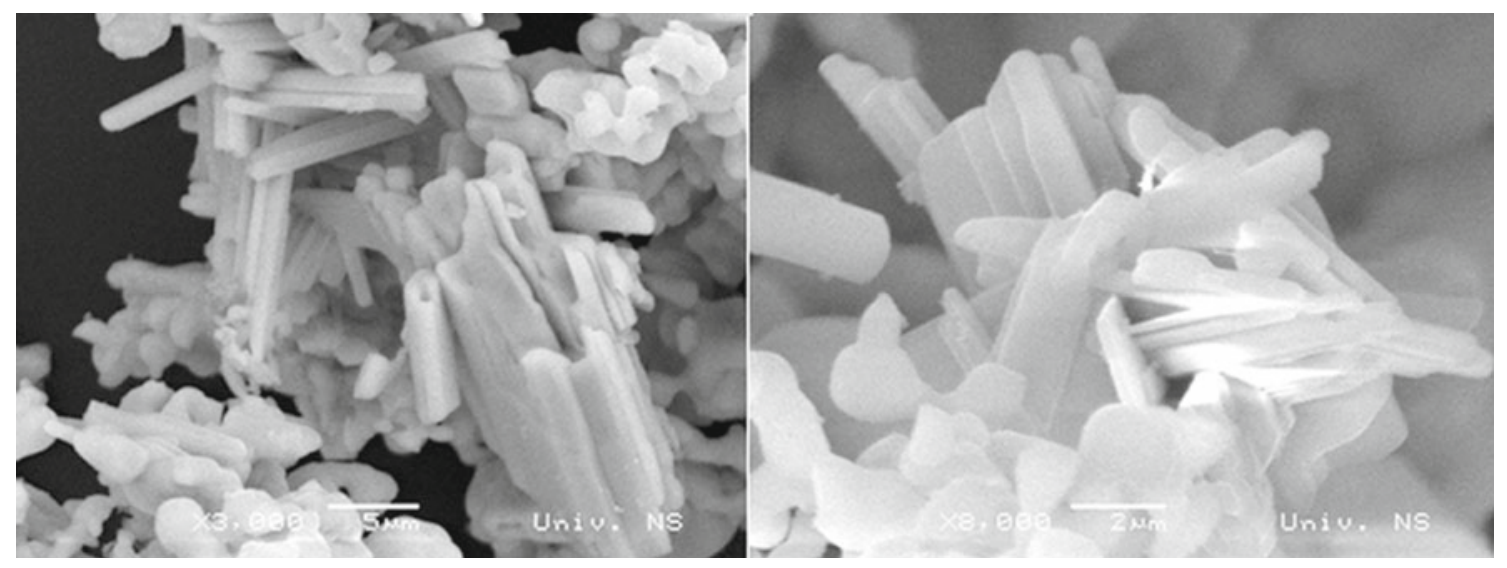

Figure 1. Typical SEM images of $\mathrm{Na}_{2} \mathrm{~W}_{2} \mathrm{O}_{7}$ particles. 
Table 1. Structure of $\mathrm{Na}_{2} \mathrm{~W}_{2} \mathrm{O}_{7}$ (space group: Cmca. Unit cell dimensions: $a=7 \cdot 22192(11) \AA, b=$ $11 \cdot 91559(17) \AA, c=14 \cdot 74755(23) \AA$. Cell content: $\left.8 \mathrm{Na}_{2} \mathrm{~W}_{2} \mathrm{O}_{7}\right)$.

\begin{tabular}{llllll}
\hline Atom & Position & $X(\sigma(X))$ & $Y(\sigma(Y))$ & $Z(\sigma(Z))$ & $B(\sigma(B))$ \\
\hline W (1) & $8(\mathrm{e})$ & $1 / 4$ & $0 \cdot 0862(1)$ & $1 / 4$ & $0 \cdot 72(4)$ \\
$\mathrm{W}(2)$ & $8(\mathrm{f})$ & 0 & $0 \cdot 2487(2)$ & $0 \cdot 0860(1)$ & $0 \cdot 91(4)$ \\
$\mathrm{Na}(3)$ & $8(\mathrm{f})$ & 0 & $0 \cdot 3311(9)$ & $0 \cdot 3360(7)$ & $0 \cdot 95(15)$ \\
$\mathrm{Na}(4)$ & $8(\mathrm{~d})$ & $0 \cdot 2474(36)$ & 0 & 0 & $0 \cdot 95(15)$ \\
$\mathrm{O}(5)$ & $16(\mathrm{~g})$ & $0 \cdot 2168(15)$ & $0 \cdot 2456(7)$ & $0 \cdot 1487(7)$ & $2 \cdot 19(28)$ \\
$\mathrm{O}(6)$ & $16(\mathrm{~g})$ & $0 \cdot 1882(20)$ & $0 \cdot 4907(7)$ & $0 \cdot 3350(7)$ & $2 \cdot 19(28)$ \\
$\mathrm{O}(7)$ & $8(\mathrm{f})$ & 0 & $0 \cdot 3347(16)$ & $0 \cdot 4920(10)$ & $2 \cdot 66(35)$ \\
$\mathrm{O}(8)$ & $8(\mathrm{f})$ & 0 & $0 \cdot 1202(12)$ & $0 \cdot 2709(11)$ & $2 \cdot 66(35)$ \\
$\mathrm{O}(9)$ & $8(\mathrm{f})$ & 0 & $0 \cdot 3843(16)$ & $0 \cdot 0176(11)$ & $2 \cdot 66(35)$ \\
\hline
\end{tabular}

Table 2. Interatomic distances and angles in $\mathrm{Na}_{2} \mathrm{~W}_{2} \mathrm{O}_{7}$.

\begin{tabular}{lllr}
\hline Octahedron & & $<\mathrm{O}-\mathrm{W}-\mathrm{O} r$ \\
$\mathrm{~W}-\mathrm{O}$ & & $5-1-5^{\prime}$ & $77 \cdot 1(3)^{\circ}$ \\
$1-5=1-5^{\prime}$ & $2 \cdot 428(9) \AA$ & $5-1-6$ & $92 \cdot 5(4)^{\circ}$ \\
$1-6=1-6^{\prime}$ & $1 \cdot 751(10) \AA$ & $5-1-6^{\prime}$ & $166 \cdot 9(5)^{\circ}$ \\
$1-8=1-8^{\prime}$ & $1 \cdot 876(4) \AA$ & $5-1-8$ & $80 \cdot 6(5)^{\circ}$ \\
& & $5-1-8^{\prime}$ & $79 \cdot 9(5)^{\circ}$ \\
O - O mean 2.96 & & $6-1-6^{\prime}$ & $98 \cdot 9(4)^{\circ}$ \\
& & $6-1-8$ & $90 \cdot 7(6)^{\circ}$ \\
& & $6-1-8^{\prime}$ & $105 \cdot 6(7)^{\circ}$ \\
& & $8-1-8^{\prime}$ & $155 \cdot 0(6)^{\circ}$ \\
Tetrahedron & & $<\mathrm{O}-\mathrm{W}_{-} \mathrm{O}$ & \\
$\mathrm{W}-\mathrm{O}$ & & $5-2-5^{\prime \prime}$ & $118 \cdot 9(4)^{\circ}$ \\
$2-5=2-5^{\prime \prime}$ & $1 \cdot 818(10) \AA$ & $5-2-7$ & $113 \cdot 7(3)^{\circ}$ \\
$2-7$ & $1.705(16) \AA$ & $5-2-9$ & $106 \cdot 6(4)^{\circ}$ \\
$2-9$ & $1.91(2) \AA$ & $7-2-9$ & $93 \cdot 7(9)^{\circ}$ \\
$\mathrm{O}-\mathrm{O}$ mean 2.93 $\mathrm{A}$ & & & \\
& & &
\end{tabular}

$\mathrm{Na}$ - O (octahedral arrangement); $\mathrm{Na}(3)$ - O mean $2.48 \AA$ 的(4) O mean $2.41 \AA$

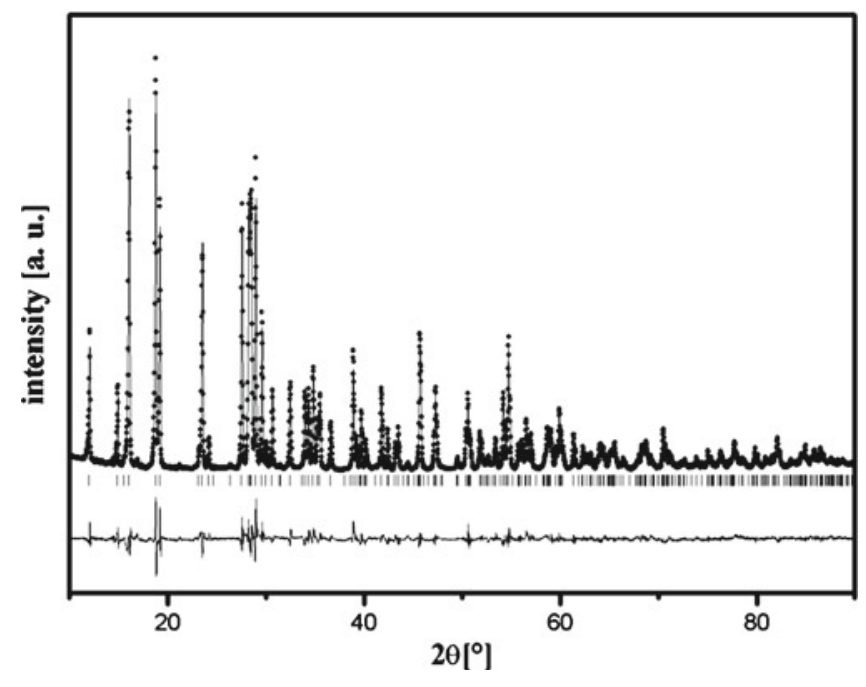

Figure 2. Final Rietveld plot of $\mathrm{Na}_{2} \mathrm{~W}_{2} \mathrm{O}_{7}$ powder.
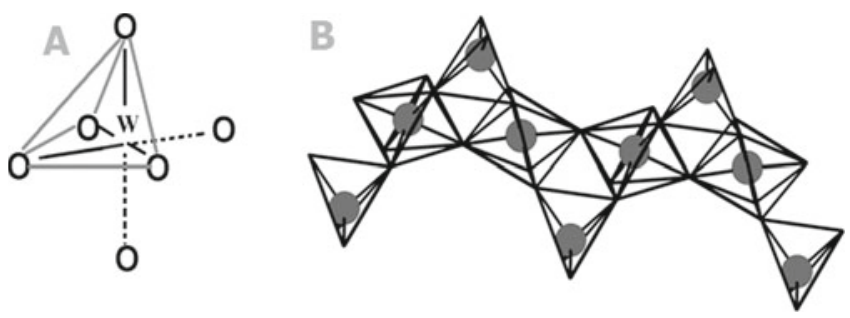

Figure 3. Octahedron as a structural unit of precursor complexes (A) and schematic presentation of structure of $\mathrm{Na}_{2} \mathrm{~W}_{2} \mathrm{O}_{7}$ solid (B).

The $\mathrm{W}(1)$ - $\mathrm{O}$ distances in the disodium ditungstate within each $\mathrm{WO}_{6}$ octahedron were found to be 2.428, 1.751 and $1.876 \AA$. For a tetrahedron, the $\mathrm{W}(2)-\mathrm{O}$ distances were found to be $1.818,1.705$ and $1.910 \AA$ (see table 2). The obtained values are in reasonable agreement with data reported by Okada et al (1975) $(2.252,1.725$ and $1.921 \AA$ for $\mathrm{W}(1)-\mathrm{O}$ and $1.807,1.759$ and $1.762 \AA$ for $\mathrm{W}(2)-$ $\mathrm{O}$, respectively), although as can be seen a small deviation in interatomic distances exist. The slight differences in values for bond angles are also present.

The $\mathrm{WO}_{6}$ octahedral building unit of the precursor complexes is shown in figure $3 \mathrm{~A}$, while the structure of $\mathrm{Na}_{2} \mathrm{~W}_{2} \mathrm{O}_{7}$ is shown in figure $3 \mathrm{~B}$. The structure of $\mathrm{Na}_{2} \mathrm{~W}_{2} \mathrm{O}_{7}$ can be described as infinite chains formed from $\mathrm{WO}_{6}$ octahedra sharing corners within the chains (Baes and Mesmer 1976). $\mathrm{WO}_{4}$ tetrahedra are bridging adjacent $\mathrm{WO}_{6}$ units.

It is clear that geometrically the same building units (octahedrons) exist in the precursor clusters and synthesized solid. Of course, there is a difference in bond lengths. However, $\mathrm{Na}_{2} \mathrm{~W}_{2} \mathrm{O}_{7}$ also contains tetrahedral units. During the course of synthesis at elevated temperature termination of the weak octahedral bonds in precursor species (dashed lines in figure $3 \mathrm{~A}$ ) may lead to the formation of tetrahedral building units.

\section{Acknowledgement}

Financial support for this study was granted by the Ministry of Science and Technological Development of the Republic of Serbia (Project III 45020). 


\section{References}

Baes C F and Mesmer R E 1976 The hydrolysis of cations (New York: Wiley)

Chai F, Tan R, Cao F, Zhai F, Wang X, Shao C and Liu Y 2007 Mater. Lett. 613939

Chatterjee S 2004 Phys. Status Solidi A 201588

Cheary R W and Coelho A A 1992 J. Appl. Crystallogr. 25109

Choudhary S N and Choudhary R N P 1998 Mater. Lett. 34411

Dahlborg M A et al 2002 J. Solid State Chem. 167525

Dickens P G and Whittingham M S 1968 Q. Rev. Chem. Soc. 2230

Hong K et al 2006 J. Cryst. Growth 29575

Kim C Y, Huh S H and Riu D H 2009 Mater. Chem. Phys. 116527

Lindqvist I 1950 Acta Chem. Scand. 41066

Okada K et al 1975 Acta Crystallogr. B31 1200
Pecharsky V K and Zavalij P Y 2005 Fundamentals of powder diffraction and structural characterization of materials (Berlin: Springer) Ch. 3

Pope M T 1983 Heteropoly and isopoly oxometalates (Berlin: Springer)

Redkin A F and Bondarenko G V 2010 J. Solution Chem. 391549

Rietveld H 1969 J. Appl. Crystallogr. 265

Sasaki Y 1961 Acta Chem. Scand. 15175

Sharma S and Choudhary R N P 1999 Ferroelectrics 234129

Tytko K H and Glemser O 1976 Adv. Inorg. Chem. Radiochem. 19239

Wang L and Bian J J 2011 Mater. Lett. 65726

Wei Q 2010 J. Cryst. Growth 3121883

Wei Q H, Shi H S, Chai W X, Qin L S and Shu K Y 2011 Chin. Phys. Lett. 28118104 